\title{
Okinawa and review of the historical records on Agent Orange
}

\author{
Alvin L Young* and Kristian L Young \\ Consulting, Inc., Cheyenne, Wyoming, USA
}

\begin{abstract}
During the past few years, there have been an increasing number of United States veterans alleging exposure to Agent Orange while serving at military installations in Okinawa during the Vietnam War Era. An extensive search of the National Archives and other government repositories was unsuccessful in finding any supporting documents validating the claims of veterans. Memories become less clear overtime. Records cannot answer or validate every question, but they can shed light on the facts as they were known at the time in which they were recorded. For Okinawa veterans, memories brought forth events that the records could clarify and illuminate with indisputable details and facts; however, those details and facts did not involve Agent Orange. There was no Agent Orange present on Okinawa.
\end{abstract}

\section{Introduction}

Agent Orange was a tactical herbicide that was used as a defoliant in the Vietnam War. Beginning with the Agent Orange Act of 1991, the United States Department of Veterans Affairs (DVA) determined that veterans who were exposed to Agent Orange or other tactical herbicides during military service may be eligible for a variety of VA benefits, including health care and disability compensation for diseases associated with alleged exposure [1]. The Act originally identified veterans with "Service in Vietnam" as eligible for benefits, but in the past 20 years the eligibility has been expanded to countries where tactical herbicides were tested, used or stored outside of Vietnam [1,2]. Hence, during the past decade the numbers of United States (US) veterans and civilians of Okinawa alleging exposure to Agent Orange while serving at or near military installations in Okinawa during the Vietnam War Era have become of great interest to the Japanese Government and the residents of the Prefecture of Okinawa [3]. The US Department of Defense (DOD) has repeatedly stated to the Government of Japan and to the US Department of Veterans Affairs that it has not found records validating these allegations [4]. Nevertheless, the allegations have continued.

\section{Background}

Burkett and Whitley in their 1998 book Stolen Valor, noted that most stories about Agent Orange suffer from the same problems; namely, reporters often don't do the very basic step of checking military records to find out if their subjects are telling the truth about their experiences [5]. While many legitimate veterans who did not exaggerate or lie about their service, sincerely believed their health problems were caused by Agent Orange, however that belief was not substantiated by the historical records or by scientific studies [5]. In the case of exposures on Okinawa, it is highly unlikely that anyone will ever prove the negative by finding a document that explicitly states that Agent Orange was never tested, stored, used or transported through Okinawa. The reality is that there are insufficient records on both sides of this controversy. Average people doing everyday jobs collected the records. Their actions were subject to error, accident, and even apathy, and were done without any knowledge at the time of what the Agent
Orange issue would become in later years. The historical records that are available cannot be guaranteed to be complete nor do they address all potential scenarios. However, they do cover the Agent Orange history from beginning (research at Fort Detrick, Maryland) to end (clean-up at former storage sites). Along with facts and numbers, e.g., production data, the records show a trend as to how the US military developed, tested, transported, stored and used tactical herbicides. So, while not every issue is covered with the same amount of paperwork, there is almost always a paper trail or trend to be followed. For Okinawa, there is no trail in the records indicating that Agent Orange was ever present.

The Investigative Reporter Jon Mitchell reviewed five years of his reporting in his recent article "Agent Orange and Okinawa: the story so far" [6]. The review included more than 25 stories that he has written on the plight of US veterans alleging exposure to Agent Orange while serving in Okinawa during the Vietnam War Era. Repeatedly he based his conclusions on the veterans recalling events that took place more than forty years ago, and unfortunately, without any validated evidence other than those recollections. Studies have proven memories to be malleable to societal influences and, hence, events are constantly reconstructed over time, especially with the assistance of intense reporting by the media [7]. The intent of this article is to document that veterans do often remember a significant event but may not remember the details. It is surely frustrating to be limited in the scope of evidence for all parties. Nevertheless, the weight of the historical evidence does not support the allegations related to Agent Orange as made by veterans, civilians or the media.

\section{The allegations}

In the past five years, there have been a series of articles published in The Japan Times and The Asia-Pacific Journal [6,8-12] alleging that

${ }^{\star}$ Correspondence to: Alvin L Young, Consulting, Inc., Cheyenne, Wyoming, USA, E-mail: youngrisk@aol.com

Key words: agent orange, okinawa, vietnam war, US veterans

Received: June 02, 2018; Accepted: June 22, 2018; Published: June 25, 2018 
Agent Orange was involved in various events on Okinawa including the following:

- That as early as 1962, Agent Orange and other tactical herbicides were tested and evaluated in the jungle areas of Okinawa;

- In Project AGILE, the first tactical herbicides were shipped from the US to Okinawa on Merchant Marine ships;

- That Agent Orange and other tactical herbicides were shipped to US military installations in Okinawa to be stored and subsequent shipped to Vietnam as needed;

- That shipments of the remaining surplus inventory of " 25,000 barrels" of Agent Orange from Vietnam were sent to Okinawa prior to shipment to Johnston Island in 1971 during Operation RED HAT;

- That quantities of Agent Orange were buried "in and around Chatan Town at Hamby Air Field", and/or "buried at White Beach near the Machinato Supply Depot" and/or "buried near the Futenma Air Station near the City of Ginowan";

- That an American Cargo Ship was stranded on a reef near Naha and drums of Agent Orange were recovered and subsequently buried; and,

- That numerous US Vietnam-era veterans stationed in Okinawa handled and sprayed Agent Orange or were witnesses to it being sprayed by a C-123 aircraft.

To assess these allegations, an in-depth search of historical records and information was conducted. The extensive search included historical records in the United States National Archives and Records Administration (NARA), College Park, Maryland. The files at NARA included the Air Force Judge Advocate Agent Orange Records from 1961 - 1983, the Department of State's Records of the Southeast Asia Bureau, the Department of State's Foreign Affairs Records on Vietnam, and many of the Military Sea Transportation Service Ship Logs. The Southwest Regional National Archives at Fort Worth, Texas provided deck logs on the Merchant Marine and US Navy ships that were alleged to have carried Agent Orange and other tactical herbicides to Okinawa.

Inquiries related to the transport, use, storage, and burial of Agent Orange on Okinawa were made with the Fort Detrick Records Manager and Records Holding Area Manager, the US Army Medical Research Institute of Infectious Diseases, the US Army Medical Research and Materiel Command, the Institute for Public Health with the US Army Public Health Command, the Naval History and Heritage Command, and the RANCH HAND Vietnam Association. Direct contact was made with the various divisions of the United States Armed Forces stationed in Japan (United States Forces Japan, USFJ). Specifically, contact was made with the Director of the Environmental Branch, USFJ/J42E, and through the Director to each of the Environmental Points of Contacts (POCs) for each of the Service Components in Japan to include Army, Navy, Air Force and Marines. In addition, contacts were made with the Commander of the United States Air Force (USAF) School of Aerospace Medicine at Kadena Air Base, and the Director, Division of Laboratory Science, US Army Public Health Command, Camp Zama, Zama, Japan.

By way of these contacts, the available historical records and the media-transcribed recounting of past events and likely scenarios were constructed out of the available evidence. As has been stated, the archives of records are limited in their completeness, but it does lend a vantage point for clarifying trends of events. For instance, vast amount of records indicated that tactical herbicides were priority and in high demand in theatre, heavy to ship, and carefully controlled. It would be impractical for a large quantity of herbicide to be transported by cargo ship to Okinawa and then moved via air transport the rest of the way to Vietnam. Nor would it be practical time wise or financially to store a large inventory of tactical herbicides in locations where they were not readily available for Operation RANCH HAND, the USAF defoliation program in Vietnam. The historical documentation would also suggest against a pattern of unlicensed and uncertified random use of restricted tactical herbicides, when commercial herbicides were approved and readily available to military personnel on Okinawa through appropriate channels.

What follows is a statement of the allegation and then a brief review of what was found from examination of the available historical records.

\section{Allegation number 1}

Agent Orange and other tactical herbicides were tested and evaluated in the jungle areas of Okinawa in 1961 - 1962 [2,3].

Review: There were no records or correspondence found that indicated that any testing and evaluation of Agent Orange occurred on Okinawa. In his book, Herbicidal Warfare: The RANCH HAND Project in Vietnam [13], Dr. Paul Cecil described the establishment and tasks of Project AGILE, a project formed to develop new counterinsurgency methods and weapons, and the first tasks were to evaluate the use of herbicides to destroy concealing vegetation and enemy food supplies in Vietnam [13]. The records located for Project AGILE indicated that the first tests of potential tactical herbicides for defoliation were conducted in 1961 and 1962 in South Vietnam, not Okinawa [14].

\section{Allegation number 2}

Beginning in 1962 in Project AGILE, the first tactical herbicides were shipped to or through, unloaded on, or used in Okinawa by the US Department of Defense during the Vietnam War. Specifically, the merchant marine ship SS Schuyler Otis Bland (T-AK277) and the SS Sooner State transported Agent Orange from the United States to Okinawa in the early 1960s [8].

Review: The actual deck logs for the USNS Schuyler Otis Bland (TAK277) were located and examined a NARA. The deck logs for the SS Sooner State were also located and examined at the Southwest Regional National Archives, Fort Worth, Texas. There was nothing in the deck logs examined at NARA or in Texas that supported the allegation that either the SS Schuyler Otis Bland or USNS S.O. Bland ever transported Agent Orange to or through Okinawa. For example, William Buckingham noted that: "The acquisition of defoliants occurred on an expedited basis. As rapidly as truckload lots accumulated, shipments left the factories for the docks at Oakland, California where port workers loaded 110,000 gallons of PURPLE and 49,000 gallons of PINK on the SS Sooner State which sailed for Saigon on December 15, 1961 and arrived on January 8, 1962 [15]."

\section{Allegation number 3}

That the Port of Naha, the adjacent US Army's Machinato Supply Depot (now Makiminato Service Area, part of the US Marine Corps Camp Kinser, bordering Urasoe City), and Kadena Air Base were used to receive large quantities of Agent Orange and store them for subsequent shipment "on merchant ships such as the USS Comet, SS Sea-Lift and the SS Transglobe, or by air transport to Vietnam during the Vietnam war" [3,9,10].

Review: There were no records found, or a DD Form 173 "Joint Message Forms" authorizing the shipment of tactical herbicides for any 
of these three ships. The search of the numerous archives and other record collections did not validate that the USS Comet, SS Sea-Lift or the SS Transglobe transported Agent Orange to Okinawa. The USNS Comet (T-AK-269) was designated a "Vehicle Cargo Ship/Roll-on/ Roll-off Ship" during the Vietnam Era. Such ships were not used for the transport of tactical herbicides. Likewise, the SS Sea Lift was also a vehicle landing ship. It was placed in service as the USNS Sea Lift (T-LSV-9) on 19 May 1967. In July of that year, it completed its maiden voyage from Oakland to Honolulu; then commenced runs to the Far East with cargo consigned to Vietnam.

\section{Allegation number 4}

That shipments of the remaining surplus inventory of 25,000 barrels of Agent Orange from Vietnam were sent to Okinawa prior to shipment to Johnston Island in 1972 during Operation RED HAT [3,17].

Review: Agent Orange was shipped directly from South Vietnam to Johnston Island as part of Air Force Logistics Command's Operation PACER IVY [16]. The movement of the Agent Orange from Vietnam to Johnston Island was NOT part of Operation RED HAT. Operation RED HAT occurred in 1971 and involved the removal of nerve and mustard gas from Okinawa to Johnston Island. Mitchell cited a report published in 2003, titled 'An Environmental Assessment of Johnston Atoll' [17]. A close examination of the 26-page 2003 report noted that the principal authors of this report were with the Boston University Marine Program and the Smithsonian National Museum of Natural History [18]. The report described the history of Johnston Atoll as a collection of events without specific references [18]. Thus, the source of the comment noted in the article was not documented in the report. However, a search of the USAF records in the National Archives provided documentation that refuted the statement that 25,000 drums of Agent Orange were stored on Okinawa prior to shipment to Johnston Island in 1972 [16,19,20]. In March 1972, the cargo ship M/T TransPacific, loaded 25,000 drums of Agent Orange from three ports/docks in South Vietnam, and on 1 April 1972 departed Saigon and arrived at Johnston Island, Central Pacific Ocean, approximately 18 days later [16]. There was no indication in the records of the ship stopping in Okinawa. Indeed, the action by the Air Force Logistics Command in Operation PACER IVY was, as noted, carefully documented in Logistics Action Directive 72-3, dated 24 March 1972 [19]. A recent publication by Edwin A. Martini, in the Journal of Military History, further elaborated on Operation PACER IVY and the subsequent disposal of Agent Orange in Operation PACER HO [20].

\section{Allegation number 5}

That a large quantity of Agent Orange was buried "in and around Chatan Town at Hamby Air Field", and/or "buried at White Beach near the Machinato Supply Depot (Service Area)", and/or "buried near the Futenma Air Station near the city of Ginowan" $[8,9]$

Review: There were no records or other evidence that Agent Orange had been found or buried on the Makiminato Service Area (MSA) shoreline or any mention of pesticides, Agent Orange, dioxin, or PCBs in the cleanup operations near the Futenma Air Station near the city of Ginowan. From the descriptions of burial sites identified in various newspaper reports, it was difficult to determine whether there were two or three alleged major burial sites of Agent Orange [9]. A report titled "Talking Paper on Possible Toxic Contamination at Camp Kinser" was prepared by the United States Forces Japan Environmental Branch (USFJ/J42E) on 30 July 1993 [21]. The Makiminato Service Area (MSA) shoreline was the site identified by US veterans formerly stationed in
Okinawa where the US military was alleged to have buried surplus Agent Orange left over from shipments of Agent Orange to Okinawa during the Vietnam War. The 30 July 1993 report stated: "There is no evidence that toxic dumping occurred off MSA - Urasoe. However, there is evidence of environmental contamination by heavy metals and pesticides caused by past hazardous material storage practices" [21]. The report noted that the chemicals included insecticides, rodenticides, herbicides, inorganic and organic acids, alkalis, organic solvents, and vapor degreasers [21]. A 2002 newspaper articles (in Japanese) described in detail the excavation and cleanup of the Chatan Town Site [22]. The cleanup operations began on 8 February 2002 and continued through 13 June 2002. Site restoration continued through October 2002. The operation removed and properly disposed of 187 drums containing "coal tar" and "oil tar", and the removal of 500 tons of contaminated soil. The total cost of the operation exceeded \$ 1 million US dollars [22].

\section{Allegation number 6}

That the American Cargo Ship USNS LST 600 was stranded on a reef near Naha and drums of Agent Orange were recovered and subsequently buried at one of the above sites $[6,9]$.

Review: No historical evidence of drums of Agent Orange recovered, or the description of "other cargo" was noted from examination of the histories of the Military Sea Transportation vessels the LST-600 or the USS Current. The Naval History and Heritage Command, Navy Yard, Washington DC provided a copy of the Command History for 1969 for the Military Sea Transportation Service's activities in Okinawa [23]. The Command History confirmed that the USNS LST 600 went aground at Kanno Se Reef near Naha on 22 December 1968 and was refloated on 17 January 1969. The vessel was an "Amphibious Tank Landing Ship" belonging to the Military Sea Transportation Service and placed in-service as USNS T-LST-600. The USS Current arrived on the scene on Christmas Day, and immediately rigged "beach gear" and with the assistance of LCM-6 Landing Craft (typically used for transport of vehicles, cargo, and personnel from ship-to-shore); cargo was offloaded to lighten the LST [23]. No mentions of drums, Agent Orange, or the description of "other cargo" were noted in either the history of the LST-600 or the USS Current. It was noted that on New Year's Day (1969), the remaining fuel was offloaded from the stranded LST. As previously noted, an LST would have been an inappropriate vessel for the transport of tactical herbicides from Mobile Bay, Alabama (the Port of Embarkation for the shipment of tactical herbicides in 1968-1969) to Vietnam. Moreover, the last shipment of Agent Orange to Vietnam was in May 1968 [16]. By mid-May 1968, the inventory of Agent Orange in Vietnam was such that the RANCH HAND Squadron requested Air Force Logistic Command to retain new stocks of Agent Orange at Mobile Bay, Alabama (subsequently the Naval Construction Battalion Center at Gulfport) until required [16].

\section{Allegation number 7}

That numerous US Vietnam-era veterans stationed in Okinawa handled and sprayed Agent Orange or were witnesses to it being sprayed by a C-123 aircraft. Moreover, some veterans claimed that they cleaned the contaminated aircraft at Kadena Air Base [6,8].

Review: No evidence from 7th Air Force (Operation RANCH HAND Quarterly Reports), Armed Forces Pest Control Board (AFPCB) Trip Reports, or any Air Staff correspondence was found that Agent Orange was ever transported or sprayed in Okinawa. AFPCB records did validate that some aerial spray operations of insecticides were conducted at the direction of PACAF's Command (Pacific Air Force) 
Medical Service Wing [24]. Major repair operations of the RANCH HAND UC-123B and K models were not conducted in Okinawa but rather in Taipei, Taiwan [13]. However, in July 1969, new UC-123K aircraft that were scheduled to join RANCH HAND in Vietnam received corrosion control treatment at Kadena Air Base [13]. Thus, the assignment of C-123Ks to Kadena Air Base had nothing to do with either defoliation operations, i.e., RANCH HAND, or insecticide operations, i.e., Operation FLYSWATER [25]. The observations by veterans that they witnessed C-123Ks flying around Kadena Air Base between January - July 1970 was certainly possible, but they were not assigned to missions involving the spraying of Agent Orange or insecticides.

\section{Conclusions}

The archives of documents frozen in time and the memories of veterans who were there - when placed together form a picture of what really happened. A shipwreck was remembered and verified within the records, but drums of petroleum were present, not Agent Orange. There were drums being stored at various military compounds, but again not drums of Agent Orange. In this case, it is also a matter of logistics that work counter to the allegation. Agent Orange was in great demand by Operation RANCH HAND in Vietnam. It would not have made any sense to store a highly needed tactical herbicide a great distance from a RANCH HAND base, let alone using Okinawa for transfer from cargo ship to cargo plane. Fifty-five gallons (208-liter) drums were extremely heavy and awkward to move about, so why move them onto a ship and then later offload the ship and onto a plane, then offload in Vietnam?

Memories have a way of fading over time, influenced by any number of societal and personal ideas. As for the records, while they are not able to answer every question, they can shed light on the facts as they were known at the time in which they were recorded. For Okinawa veterans, memories brought forth events that the records could clarify and illuminate with indisputable details and facts; however, those details and facts did not involve Agent Orange. There was no Agent Orange present on Okinawa.

\section{Acknowledgement}

This article partially relied on research completed for and funded by the Department of Defense through a contract with Oak Ridge Institute for Science and Education (ORISE), and by the United States Department of Veterans Affairs. The views and opinions expressed in this article do not necessarily represent those of ORISE, the Department of Defense, or any other Department or Agency of the United States Government.

\section{References}

1. Department of Veterans Affairs (2015): Health Care. http://www.va.gov/health

2. Young AL (2006) The History of the US Department of Defense Programs for the Testing, Evaluation, and Storage of Tactical Herbicides. Report submitted by A.L. Young Consulting, Inc. to Office of the Under Secretary of Defense, Crystal Gateway 2, Suite 1500, 1225 Jefferson Davis Hwy, Arlington VA 22202.

3. Mitchell J (2011) U.S. Military Defoliants on Okinawa: Agent Orange. The AsiaPacific Journal 9 (37), No. 5, September 12, 2011.

4. Young AL, Young KL (2013) Investigations into Allegations of Herbicide Orange on Okinawa, Japan. Report submitted by A. L. Young Consulting, Inc., to Office of the Deputy Under Secretary of Defense (I\&E), 4800 Mark Center Drive, Alexandria, VA 22350-3605.

5. Burkett BG, Whitley G (1998) Stolen Valor: How the Vietnam Generation was Robbed of its Heroes and its History. Chapter 22: The Myth of Agent Orange, pp 527-552, Verity Press, Inc., Dallas, TX, USA.
6. Mitchell J (2016) Agent Orange and Okinawa: the story so far. Special to the Japan Times, April 27, 2016.

7. McCowan K (2009) How much of your memory is true (new research shows that memories are constantly being re-written by our minds). Discover Magazine, 03 August 2009.

8. Mitchell J (2012) Defoliated Island - Agent Orange, Okinawa and the Vietnam War, Asia-Pacific Journal Feature, TV documentary.

9. Mitchell J (2012) Agent Orange at Okinawa's Futenma Base in 1980s. The Asia-Pacific Journal 10: 3

10. Mitchell J (2013) Okinawa - The Pentagon's Toxic Junk Heap of the Pacific. The AsiaPacific Journal 11: 6.

11. Mitchell J (2015) Pentagon blocks report on 'toxic contamination' at base outside Okinawa capital. The Japan Times, September 16, 2015.

12. Mitchell J (2015) FOIA Documents Reveal Agent Orange Dioxin, Toxic Dumps, Fish Kills on Okinawa Base. The Asia-Pacific Journal 13: 1.

13. Cecil PF (1986) Herbicidal Warfare: The RANCH HAND Project in Vietnam. Praeger Special Studies, Praeger Scientific, New York, NY, USA.

14. Brown JW (1962) Vegetational Spray Tests in South Vietnam, Biological Laboratories, US Army Chemical Corps, Fort Detrick MD (Available from the Alvin L. Young Agent Orange Collection, National Agricultural Library, Accession No. 00336).

15. Buckingham WA (1982) OPERATION RANCH HAND: The Air Force and Herbicides in Southeast Asia, 1961-1971. Office of Air Force History, Bolling Air Force Base, Washington DC, USA.

16. Young AL (2009) The History, Use, Disposition and Environmental Fate of Agent Orange. Springer Science + Business Media, LLC, New York, NY, USA.

17. Mitchell J (2012) 25,000 barrels of Agent Orange kept on Okinawa, U.S. Army document says. The Japan Times, August 7, 2012.

18. Lobel P, Schreiber EA (2003) An Ecological Assessment of Johnston Atoll. JACADS Publications, US Army Chemical Materials Activity, Aberdeen Proving Grounds MD, USA.

19. Logistics Action Directive (24 March 1972) Vietnam ORANGE Herbicide Removal Logistics Action Directive 72-3, Headquarters, Pacific Air Force, APO, San Francisco (Copy obtained from USAF Records, Washington National Records Center, Suitland MD, USA).

20. Martini EA (2012) Incinerating Agent Orange: Operations PACER HO and PACER IVY, and the Rise of Environmentalist Thinking. Journal of Military History 76: 809836.

21. Joint Environmental Investigative Committee (30 July 1993) Talking Paper on Possible Toxic Contamination at Camp Kinser. Environmental Branch (J42E), United States Forces Japan (USFJ), Yokota Air Base, Japan.

22. Series of Newspaper Articles in Japanese (8 February-10 August 2002) Working Title: Cleanup Operations, Hamby Area, Chatan, Okinawa. Published as Recent News, Ryukyu Shimpo Newspaper, Japan.

23. Department of the Navy, Military Sea Transportation Service Office (February 1971) Command History, Military Sea Transportation Service Office, Okinawa, Japan. Obtained from the Naval History and Heritage Command, Navy Yard, Washington DC, USA.

24. Reisen WK, Burns JP, Basio RG (April 1971) The Distribution and Abundance of Mosquitoes on USAF Installations in Asia for 1970. 1st Medical Service Wing (PACAF) (Available from the Armed Forces Pest Management Board, Silver Springs MD, USA).

25. Cecil PF Sr, Young AL (2008) Operation FLYSWATTER: a war within a war. Environ Sci Pollut Res Int 15: 3-7. [Crossref]

Copyright: (C)2018 Young AL. This is an open-access article distributed under the terms of the Creative Commons Attribution License, which permits unrestricted use, distribution, and reproduction in any medium, provided the original author and source are credited. 